\title{
Mechanisms Underlying T Cell Immunosenescence: Aging and Cytomegalovirus Infection
}

\author{
Wenjuan Tu and Sudha Rao * \\ Faculty of ESTeM, Health Research Institute, University of Canberra, Canberra, ACT, Australia
}

The ability of the human immune system to protect against infectious disease declines with age and efficacy of vaccination reduces significantly in the elderly. Aging of the immune system, also termed as immunosenescence, involves many changes in human $T$ cell immunity that is characterized by a loss in naïve $T$ cell population and an increase in highly differentiated CD28- memory $T$ cell subset. There is extensive data showing that latent persistent human cytomegalovirus (HCMV) infection is also associated with age-related immune dysfunction in the T cells, which might enhance immunosenescence. Understanding the molecular mechanisms underlying age-related and HCMV-related immunosenescence is critical for the development of effective age-targeted vaccines and immunotherapies. In this review, we will address the role of both aging and HCMV infection that contribute to the T cell senescence and discuss the potential molecular mechanisms in aged T cells.

Edited by:

Akio Adachi,

Tokushima University, Japan

Reviewed by:

Rafael Solana,

University of Córdoba, Spain

Vijayakumar Velu,

Emory University, USA

Christopher M. Snyder,

Thomas Jefferson University, USA

*Correspondence:

Sudha Rao

sudha.rao@canberra.edu.au

Specialty section:

This article was submitted to

Virology,

a section of the journal

Frontiers in Microbiology

Received: 09 July 2016

Accepted: 13 December 2016

Published: 27 December 2016

Citation:

Tu W and Rao S (2016) Mechanisms Underlying T Cell Immunosenescence: Aging and Cytomegalovirus Infection.

Front. Microbiol. 7:2111.

doi: 10.3389/fmicb.2016.02111
Keywords: immunosenescence, naive and memory T cells, aging, HCMV infection, epigenetic regulation, vaccination

\section{THE AGING IMMUNE SYSTEM}

The human immune system must fight diverse pathogens and provide sufficient host protection throughout life. Memory T cells, which differentiate from naïve T cells upon primary antigenic stimulation and enable a rapid and robust response to previously encountered pathogens, are key players in adaptive immunity. The generation and maintenance of pathogen-specific memory $\mathrm{T}$ cells is crucial for life-long immune protection and effective vaccination (Farber et al., 2014). However, profound changes occur in the human immune system over time, known as immunosenescence. These age-related changes contribute to decreased immune protection against infections and diminished responses to vaccination in the elderly. Changes in $\mathrm{T}$ cell immunity appear to be have the most impact (Miller, 1996; Cambier, 2005).

Although T cell numbers remain more or less constant over the human lifespan, pronounced age-associated changes occur in $\mathrm{T}$ cell composition (naïve vs. memory $\mathrm{T}$ cell subsets). It is well accepted that the functional naïve $\mathrm{T}$ cell output decreases after puberty due to thymic involution, resulting in increased homeostatic proliferation of existing naïve $\mathrm{T}$ cells and eventually phenotypic conversion of naïve T cells into virtual memory cells (Nikolich-Žugich, 2008, 2014; Goronzy et al., 2015; Jacomet et al., 2015). In contrast to the shrinking naïve compartment and its impaired ability to activate and differentiate with age, the proportion of memory $\mathrm{T}$ cells increases during early life, remains stable throughout adulthood, but starts to show senescent changes after about 65 years (Farber et al., 2014). In humans, circulating memory $\mathrm{T}$ cells can be subdivided into two major phenotypically and functionally distinct populations: central memory $\mathrm{T}$ cells 
$\left(\mathrm{T}_{\mathrm{CM}} ; \mathrm{CD} 4 \mathrm{RA}^{-} \mathrm{CCR}^{+} \mathrm{CD}^{-\mathrm{L}^{+}}\right.$), which are largely confined to secondary lymphoid tissues, and effector memory $\mathrm{T}$ cells ( $\mathrm{T}_{\mathrm{EM}}$; CD45RA ${ }^{-} \mathrm{CCR}^{-} \mathrm{CD}^{-} \mathrm{L}^{-}$), which can traffic to multiple peripheral compartments (Sallusto et al., 1999; Mueller et al., 2013; Farber et al., 2014). $\mathrm{T}_{\mathrm{CM}}$ cells are enriched for CD4 ${ }^{+} \mathrm{T}$ cells, while $\mathrm{T}_{\mathrm{EM}}$ cells are predominantly $\mathrm{CD}^{+} \mathrm{T}$ cells in human blood (Moro-García et al., 2013).

One of the most prominent $\mathrm{T}$ cell changes to occur with age is the loss of the co-stimulatory molecule CD28 and the progressive accumulation of highly differentiated $\mathrm{CD} 28^{-}$ $\mathrm{T}_{\mathrm{EM}}$ cells $\left(\mathrm{CD} 4 \mathrm{RA}^{+} \mathrm{CD} 28^{-} \mathrm{CCR}^{-} \mathrm{CD}^{-} \mathrm{L}^{-}\right)$, mainly in the $\mathrm{CD}^{+} \mathrm{T}$ cell population (Koch et al., 2008). These cells are characterized by decreased proliferative capacity, shortened telomeres, a reduced TCR repertoire, and enhanced cytotoxic activity. As CD28 is crucial for complete T cell activation, CD28 loss is associated with increased susceptibility to infections and a weakened immune response to vaccination in older people (Saurwein-Teissl et al., 2002; Almanzar et al., 2005; Sansoni et al., 2008; Moro-García et al., 2013). However, CD28 ${ }^{-}$T cells are not anergic, so they might also play a role in tissuemediated immunity $\left(\mathrm{CD}^{+} \mathrm{CD} 28^{-} \mathrm{T}\right.$ cells) (Flavell et al., 2013) and cytomegalovirus (CMV) infection control $\left(\mathrm{CD} 4^{+} \mathrm{CD} 28^{-} \mathrm{T}\right.$ cells) (Moro-García et al., 2013). Further studies to explore the generation and maintenance of $\mathrm{CD} 28^{-} \mathrm{T}$ cells, especially in different disease states, will help establish their immune function and enhance our understanding of human T cell aging.

It is thought that the memory $\mathrm{T}$ cells generated in youth are well preserved and remain strongly protective over decades (Hammarlund et al., 2003, 2005), while T cell memory responses first derived in old age are severely impaired (Haynes et al., 2003; Weinberger et al., 2008; Nikolich-Žugich and Rudd, 2010; Valkenburg et al., 2012). Therefore, age-targeted vaccines and immunotherapies are required.

The ability to generate protective immune responses largely depends on the generation and maintenance of a diverse and well-balanced $\mathrm{T}$ cell repertoire. Several studies have shown contraction in $\mathrm{T}$ cell diversity corresponding to a shrinkage in the naïve T cell compartment in elderly individuals due to thymic involution (Naylor et al., 2005; Britanova et al., 2014). However, these studies do not take the dramatic influence of latent persistent infection into account, particularly CMV infection, which is known to be associated with age-related alterations in the $\mathrm{T}$ cell pool and function. Recent evidence suggests that homeostatic proliferation maintains the naïve $\mathrm{CD}^{+} \mathrm{T}$ cell compartment and its diverse repertoire, but not naïve $\mathrm{CD} 8^{+} \mathrm{T}$ cells, in CMV-negative individuals. A decline in naïve $\mathrm{CD} 4^{+}$ $\mathrm{T}$ cell subsets occurs in the presence of CMV, but there is no depletion of naïve $\mathrm{CD}^{+} \mathrm{T}$ cells (Wertheimer et al., 2014). In principle, thymic involution should have an equal impact on both $\mathrm{CD}^{+}{ }^{+}$and $\mathrm{CD}^{+}{ }^{+} \mathrm{T}$ cells. Therefore, the differences seen between the two subsets suggest that shrinkage of the naïve $\mathrm{CD}^{+} \mathrm{T}$ cell pool is more likely to be due to increased development of virtual memory $\mathrm{T}$ cells (which are well characterized in murine models Sprent and Surh, 2011; Renkema et al., 2014) than the defective regeneration ability of an aged thymus. Moreover, unprimed "innate/memory-like" CD8 ${ }^{+} \mathrm{T}$ cells have recently been identified in humans (Jacomet et al., 2015). Taken together, these data imply that thymic involution might be less important for maintaining $\mathrm{T}$ cell diversity than previously thought. Characterization of the epigenetic signatures and transcriptional profiles of these virtual memory $\mathrm{T}$ cells will help explain how antigen-inexperienced $\mathrm{T}$ cells acquire the memory phenotype and how they contribute to the aging immune system.

Given that polyfunctional $\mathrm{T}$ cells confer a more effective immune response to infections (Yamamoto et al., 2009; Boyd et al., 2015; Snyder et al., 2016), it is important to investigate the impact of aging on $\mathrm{T}$ cell polyfunctionality. Van Epps et al. demonstrated enhanced polyfunctionality in $\mathrm{CD}^{+} \mathrm{T}_{\mathrm{EM}}$ cell subsets in older individuals, but both $\mathrm{CD}^{+}$and $\mathrm{CD}^{+}{ }^{+} \mathrm{T}_{\mathrm{CM}}$ cells exhibited an age-associated decline in polyfunctionality (Van Epps et al., 2014). However, the CMV-seropositive reaction was again not examined, and the possibility that increased polyfunctional $\mathrm{CD}^{+} \mathrm{T}_{\mathrm{EM}}$ cells may be due to repeated antigenic stimulation could not, therefore, be excluded.

Despite intensive studies of $\mathrm{T}$ cells providing some insights into immune system aging, they have a number of limitations that need to be taken into consideration in future investigations. First, most of our current knowledge on $\mathrm{T}$ cell aging is based on studies of circulating peripheral blood $\mathrm{T}$ cells, which only represent $2 \%$ of the total $\mathrm{T}$ cell pool (Farber et al., 2014). Circulating memory $\mathrm{T}$ cells predominantly reside in tissues other than the blood (Mueller et al., 2013). In addition, a non-circulating subset of memory $\mathrm{T}$ cells has recently been identified and designated tissue-resident memory $\mathrm{T}$ cells $\left(\mathrm{T}_{\mathrm{RM}}\right.$; $\mathrm{CD}_{5} \mathrm{RA}^{-} \mathrm{CCR}^{-} \mathrm{CD}^{-} 2 \mathrm{~L}^{-} \mathrm{CD}^{+} 9^{+}$), which permanently reside in peripheral tissues and enhance local immunity during infections (Mueller et al., 2013; Farber et al., 2014; Clark, 2015). However, age-related changes in naïve and memory $\mathrm{T}$ cells in distinct human organs have only rarely been studied (Lazuardi et al., 2005; Herndler-Brandstetter et al., 2012; Sathaliyawala et al., 2013). Second, most studies are limited to the total $\mathrm{CD}^{+}{ }^{-} \mathrm{T}$ cell pool with only a few studies conducted in Th1 and Th2 $\mathrm{CD}^{+}{ }^{+} \mathrm{T}$ cell subsets, and even less is known about the impact of aging on other lineages, such as Th17 cells (Huang et al., 2008; Tesar et al., 2009; Lee et al., 2011; Lim et al., 2014), regulatory T cells (Tregs) (Fessler et al., 2013; Garg et al., 2014), and Tfh cells (Winkler and Waisman, 2014; Zhou et al., 2014). Finally, human memory $\mathrm{T}$ cells are generated and maintained in the context of exposure to diverse viral infections throughout life, particularly CMV infection (over $90 \%$ of young people in developing countries) (Arens et al., 2015). It is well-known that CMV plays an important role in human memory $\mathrm{T}$ cell function with aging. Therefore, distinguishing CMV seropositive individuals from others is important to provide a more accurate understanding of age-related memory $\mathrm{T}$ cell immunity. The enormous impact of CMV infection on T cell function with aging is further discussed below.

\section{MOLECULAR MECHANISMS OF T CELL SENESCENCE}

Although the impact of aging on $\mathrm{T}$ cells is relatively well described at the cellular level, the molecular mechanisms of 
aging are rather less well understood. There is growing evidence that altered transcription (Chen et al., 2013) and epigenetic regulation (Ponnappan and Ponnappan, 2011) are involved in $\mathrm{T}$ cell senescence.

A major feature of immunological memory is the ability of $\mathrm{T}$ cells to remember their previous transcriptional profile and propagate their gene expression pattern to progeny, termed "adaptive transcriptional memory" (Turner, 2003; Kundu and Peterson, 2009). In transcriptional or epigenetic memory, genes are marked with active epigenetic signatures that are maintained throughout multiple cell divisions. These marks facilitate more efficient and robust transcription upon encountering a secondary stimulus (Zediak et al., 2011).

Chen et al. provided an excellent overview of the impact of aging on genome-wide transcriptional profiles in $\mathrm{CD}_{4}^{+}$and $\mathrm{CD}^{+} \mathrm{T}$ cells (Chen et al., 2013). For example, $\mathrm{CD}^{+} \mathrm{T}$ cells (Fann et al., 2005), and to a lesser degree $\mathrm{CD}^{+} \mathrm{T}$ cells (Czesnikiewicz-Guzik et al., 2008), decrease CD28 gene expression with age, with $\mathrm{CD} 28^{+}$and $\mathrm{CD} 28^{-} \mathrm{CD} 8^{+}$memory $\mathrm{T}$ cells showing different transcriptional profiles. There was elevated expression of several transcription factors including T-bet, eomesodermin (EMOES), and MYC (Fann et al., 2005) in $\mathrm{CD} 28^{-}$memory $\mathrm{T}$ cells. T-bet and EMOES play crucial roles in the acquisition of $\mathrm{T}$ cell effector functions and memory development in $\mathrm{CD}^{+} \mathrm{T}$ cells and regulate IFN $-\gamma$, granzyme $B$, and perforin expression (Angelosanto and Wherry, 2010), suggesting that they might critically mediate the enhanced cytotoxicity of $\mathrm{CD}^{2} 8^{-} \mathrm{CD} 8^{+}$memory $\mathrm{T}$ cells. In addition, mammalian target of rapamycin (mTOR) has been shown to modulate memory $\mathrm{CD}^{+} \mathrm{T}$ cell formation by regulating $\mathrm{T}$ bet and EMOES gene expression. mTOR inhibition promotes $\mathrm{T}$ cell memory by repressing $\mathrm{T}$-bet and inducing EOMES (Rao et al., 2010). Remarkably, the mTOR inhibitor RAD001 has recently been reported to improve immune responses to influenza vaccination in elderly volunteers, but the underlying mechanism remains obscure (Mannick et al., 2014). Two possible mechanisms might explain this observation. First, Tbet expression is higher in terminally differentiated $\mathrm{T}_{\mathrm{EM}}$ cells (Joshi et al., 2011), while EOMES is highly expressed in persistent $\mathrm{T}_{\mathrm{CM}}$ cells (Banerjee et al., 2010). Therefore, RAD001 might restrain the conversion of memory $\mathrm{T}$ cells to a highly differentiated phenotype, such as $\mathrm{CD} 28^{-} \mathrm{T}_{\mathrm{EM}}$ cells, by reducing T-bet expression in the elderly. As a consequence, $\mathrm{T}$ cell senescence is suppressed and the immunological function of memory $\mathrm{T}$ cells enhanced. Second, T-bet is also the master regulator of Th1 cell differentiation but is inhibitory in Th2 and Tfh cell lineage development (Lazarevic et al., 2013). Zang et al. found a Th1 $\mathrm{CD}^{+}{ }^{+}$subset shift and reduced Th2/Tfh cell differentiation in aged mice (Zhang et al., 2014). Hence, the decrease in T-bet caused by RAD001 might enhance Th2 and/or Tfh $\mathrm{CD}^{+}$cell development, which is crucial for B cell immunity and antibody production. This latter hypothesis is further supported by clinical observations of an increased antibody response in elderly volunteers receiving the influenza vaccination (Mannick et al., 2014). Further studies of cellular and molecular changes occurring in these different subsets are needed.
Numerous studies have shown that epigenetic mechanisms including DNA methylation, histone modifications, chromatin structure alterations, and microRNA regulation play an essential role in transcriptional memory by regulating gene expression in memory T cells (Gibney and Nolan, 2010). It is well-known that genome-wide decreases in the methylation of repetitive elements (particularly Alu sequences) and gene coding regions occur during aging (Bollati et al., 2009; Heyn et al., 2012; Salpea et al., 2012). These age-dependent DNA methylation changes also occur in immune-specific genes that contribute to $\mathrm{T}$ cell senescence (Shanley et al., 2009; Fernández-Morera et al., 2010; Hongdong et al., 2015; Tserel et al., 2015).

Although the age-associated DNA methylation signatures that mark immune responsive genes are well documented, little is known about the contribution of site-specific histone modifications to immunosenescence. Histone acetylation, methylation, phosphorylation, and ubiquitination all regulate transcription by altering chromatin accessibility (Strahl and Allis, 2000; Kouzarides, 2007). Early epigenetic studies in rat livers showed significant decreases in histone acetylation (H3K9ac) and $\mathrm{H} 3$ phosphorylation (H3S10ph) contributing to age-associated decreases in transcription (Kawakami et al., 2008). More recently, Sidler et al. demonstrated profound age-dependent changes in gene expression accompanied by decreases in DNA methylation, H3K9me3, and H4K16ac in the rat spleen and thymus, suggesting increased chromatin instability with age. Moreover, several transcription factors (BCL6, MYC, TCF7, and ETS1) with decreased expression in the thymus and increased expression in the spleen are thought to be associated with immunosenescence (Sidler et al., 2013). Since these transcription factors play crucial roles in homeostatic proliferation, differentiation, and activation in $\mathrm{T}$ lymphocytes (Muthusamy et al., 1995; Angelosanto and Wherry, 2010), their opposing transcriptional profiles in the thymus and spleen might contribute to the distinct senescence phenotype observed during aging, i.e., the reduced thymic naïve $\mathrm{T}$ cell output and increased homeostatic proliferation of peripheral $\mathrm{T}$ cells. Chromatin immunoprecipitation (ChIP) studies to identify genome-wide epigenetic signatures with characterization of chromatin accessibility in these regions might provide insights into the epigenetic regulation of immunosenescence.

Several recent studies have explored microRNA regulation in $\mathrm{T}$ cell aging. For example, miR-92a expression significantly declined in $\mathrm{CD}^{+} \mathrm{T}$ cells during aging, which also correlated with reduced naïve $\mathrm{CD}^{+} \mathrm{T}$ cell numbers. It has also been suggested that the progressive decline in miR-92a expression may be associated with a reduced naïve $\mathrm{T}$ cell repertoire due to repeated stimulus exposure (Ohyashiki et al., 2011). Moreover, an age-dependent decline in miR-181a, an intrinsic regulator of TCR signaling ( $\mathrm{Li}$ et al., 2007), was observed in aged CD4 ${ }^{+} \mathrm{T}$ cells (Li et al., 2012). miR-181a loss increased DUSP6 activity, which eventually impaired TCR sensitivity in elderly $\mathrm{CD} 4^{+} \mathrm{T}$ cells ( $\mathrm{Li}$ et al., 2012). Compared to $\mathrm{CD} 8^{+} \mathrm{CD} 28^{+} \mathrm{T}$ cells, highly differentiated $\mathrm{CD} 8^{+} \mathrm{CD} 28^{-} \mathrm{T}$ cells overexpressed miR-24, which was associated with downregulation of the histone variant $\mathrm{H} 2 \mathrm{AX}$ and consequent impairment of the response to DNA damage and increased susceptibility to apoptosis in $\mathrm{CD}^{+} \mathrm{CD} 28^{-} \mathrm{T}$ cells 
(Brunner et al., 2012). Taken together, these studies suggest that microRNAs are causative in immunosenescence and might be useful biomarkers of $\mathrm{T}$ cell aging. However, a systematic survey of microRNAs, their direct targets, and function in immunosenescence are needed. Comprehensive studies in welldefined human $\mathrm{T}$ cell subsets in both health and disease will enhance our understanding of the molecular mechanisms responsible for age-related $\mathrm{T}$ cell impairment so that effective interventional strategies against age-associated diseases can be developed.

Apart from genetic/epigenetic inheritance, lifestyle and environmental factors, such as nutritional status and metabolism also have a significant impact on the human immune system and lifespan (Fuente, 2014). There is good evidence that diets that contain particular nutrient or non-nutrient components can significantly enhance immune function in the elderly (Lesourd et al., 1998; Pae et al., 2011; Maijó et al., 2014). For example, dietary manipulation of the availability of methyl donors can extend and maintain immune function by epigenetically modulating methylation in mice (Miller et al., 2005). The mTOR pathway has provided a focus for understanding how metabolism regulates $\mathrm{T}$ cell immunity: upon growth factor stimulation, the PI3K/Akt/mTOR pathway is activated that, in turn, promotes nutrient uptake, enhances many metabolic activities, and results protein biosynthesis in $\mathrm{T}$ cells (Jones and Thompson, 2007). The mTOR inhibitor rapamycin promotes $\mathrm{CD}^{+} \mathrm{T}$ cell memory development (Araki et al., 2009), which might be due to metabolic changes in $\mathrm{CD}^{+} \mathrm{T}$ cells (Peng et al., 2002; Sipula et al., 2006; Brown et al., 2007). Moreover, mTOR plays a crucial role in the regulation of effector and regulatory $\mathrm{T}$ cell lineage commitment (Delgoffe et al., 2009), since it not only acts as a regulator of translation but also functions as an intracellular energy sensor that positively and directly regulates mitochondrial respiration (Desai et al., 2002; Ramanathan and Schreiber, 2009). A study of energy metabolism has shown that highly differentiated $\mathrm{CD} 8^{+} \mathrm{CD} 28^{-} \mathrm{T}$ cells utilize different metabolic strategies than normal $\mathrm{CD}^{+}$memory $\mathrm{T}$ cells (Henson et al., 2014); in contrast to the quiescent catabolic metabolism in $\mathrm{CD}^{+} \mathrm{CD}^{+} 8^{+}$memory $\mathrm{T}$ cells, $\mathrm{CD} 8^{+} \mathrm{CD} 28^{-} \mathrm{T}$ cells have lower mitochondrial mass and respiration, high basal glycolysis levels, and impaired metabolism due to increased ROS levels (Henson et al., 2014). Further, $\mathrm{CD} 8^{+} \mathrm{CD} 28^{-} \mathrm{T}$ cells favor the use of the cytosolic glycolytic pathway over mitochondrial respiration for energy production. Aerobic glycolysis is a critical metabolic pathway required for the production of the effector cytokine IFN- $\gamma$, consistent with the enhanced cytotoxic activity of CD8 ${ }^{+} \mathrm{CD} 28^{-}$T cells (Chang et al., 2013; Gubser et al., 2013). As mitochondrial function is compromised during aging (Ronharel et al., 2015), a switch to energy generation by glycolysis may produce a population of $\mathrm{CD}^{+} \mathrm{CD} 28^{-}$T cells with the metabolic advantage to outcompete other $\mathrm{T}$ cell subsets competing for nutrients and factors required for survival and function. These data highlight the important role played by nutrient status and metabolic regulation in enhancing $\mathrm{T}$ cell immunity and might be a promising approach to promote healthy aging through nutritional and metabolic interventions.

\section{HUMAN CMV INFECTION, MEMORY INFLATION, AND IMMUNOSENESCENCE}

Cytomegalovirus (CMV) is an ubiquitous $\beta$-herpesvirus with a double-stranded DNA genome that has co-evolved with humans over millions of years (Sinclair and Sissons, 2006; Gibson, 2008). Human CMV (HCMV) is a prevalent human pathogen, infecting $40-100 \%$ of world's population. CMV has the capacity to induce both lytic and latent infections to establish lifelong persistence in human hosts following primary infection (Cannon, 2009; Ludwig and Hengel, 2009; Cannon et al., 2010). In lytic infection, HCMV undergoes temporally active replication that can be divided into immediate early (IE), early (E), and late (L) phases. The most crucial viral lytic gene products are viral IE genes, which control subsequent viral gene expression and virus replication. Thus, these major IE gene products essentially determine the HCMV infection states: latency (IE genes suppressed) or reactivation (IE genes expressed) (Sinclair and Sissons, 2006; Paulus and Nevels, 2009). The latent phase of HCMV infection is characterized by viral quiescence, in which the viral genome is maintained as an extra-chromosomal plasmid in the absence of detectable production of infectious virions but able to reactivate to specific stimuli (Goodrum et al., 2002; Reeves et al., 2005; Sinclair and Sissons, 2006). Despite infecting a broad range of host cells, HCMV usually establishes viral latency at specific cellular sites, predominantly $\mathrm{CD}_{3}{ }^{+}$progenitors and myeloid lineage cells (Hahn et al., 1998; Goodrum et al., 2002).

Primary HCMV infection elicits extensive innate and adaptive immune responses. Thus, to escape host antiviral responses, HCMV has developed diverse immune evasion strategies to alter host immune recognition during both lytic and latent infection. In particular, HCMV restricts major histocompatibility complex (MHC) class I and II antigen presentation, which allows the virus to survive, disseminate, and persist in infected individuals (Noriega et al., 2012). In immunocompetent individuals, both primary and lifelong persistent $\mathrm{HCMV}$ infections generally remain subclinical and well controlled by the host immune system. T cell responses are particularly important for controlling viral latency in infected individuals (Hanley and Bollard, 2014; Klenerman and Oxenius, 2016). During the early phases of primary infection, the initial $\mathrm{T}$ cell response to $\mathrm{HCMV}$ is dominated by circulating HCMV-specific $\mathrm{CD}^{+}{ }^{+} \mathrm{T}$ cells that produce the Th1 cytokines IFN- $\gamma$ and TNF- $\alpha$ (Rentenaar et al., 2000; Gamadia et al., 2003). Highly cytotoxic HCMV-specific $\mathrm{CD}^{+} \mathrm{T}$ cells can be detected in the blood several days after the initial $\mathrm{CD}^{+} \mathrm{T}$ cell response, and they are maintained with an effector phenotype during the latent phase to prevent HCMV reactivation and to protect the host from re-infection (Polić et al., 1998; Kuijpers et al., 2003; Mackus et al., 2003). In addition, the humoral response to HCMV also contributes to controlling the viral load and preventing primary infection in humans (Gerna et al., 2008; Genini et al., 2011; Jackson et al., 2011; Alonso Arias et al., 2013). After primary infection, B cells are activated by antigens with the help of $\mathrm{HCMV}$-specific $\mathrm{CD} 4^{+} \mathrm{T}$ cells, mainly Th2 cells, leading to the production of antibodies specific for a number of HCMV proteins (Wang and Shenk, 2005; Gerna et al., 
2008; Macagno et al., 2010; Genini et al., 2011). These HCMVspecific antibodies can block viral dissemination and control the infection by neutralizing extracellular virions, a mechanism that is particularly important for protecting the fetus from congenital HCMV infection (Fowler et al., 1992; Revello and Gerna, 2002; Schleiss, 2013).

However, long-term HCMV persistence has a profound impact on the immune system's composition and function, even in healthy HCMV-infected individuals, especially with respect to $\mathrm{CD}^{+} \mathrm{T}$ cells. One hallmark of latent HCMV infection is the progressive and substantial expansion of HCMV-specific memory $\mathrm{CD}^{+}{ }^{+} \mathrm{T}$ cells over time, with HCMV-specific memory $\mathrm{CD}^{+} \mathrm{T}$ cells accumulating to a lesser extent (Klenerman and Oxenius, 2016; Weltevrede et al., 2016). This accumulation of HCMV-specific memory $\mathrm{T}$ cells during viral persistence is termed "memory inflation," first defined in the mouse CMV (MCMV) infection model (Karrer et al., 2003). HCMV-specific memory $\mathrm{T}$ cells tend to gradually increase in number with age: in HCMV-infected elderly individuals, the $\mathrm{CD}^{+} \mathrm{T}$ cell response to $\mathrm{HCMV}$ antigens occupies nearly $50 \%$ of the entire memory $\mathrm{CD}^{+} \mathrm{T}$ cell compartment in peripheral blood, while approximately $30 \%$ of total circulating $\mathrm{CD} 4^{+} \mathrm{T}$ cells can be HCMV responsive (Sylwester et al., 2005; Pourgheysari et al., 2007; Li et al., 2014).

Human cytomegalovirus (HCMV) persistence is thought to be a driver of immunosenescence in humans (Koch et al., 2007). The majority of HCMV-specific inflationary $\mathrm{T}$ cells are $\mathrm{T}_{\mathrm{EM}}$ cells with the typical age-related senescent $\mathrm{T}$ cell phenotype. These terminally differentiated HCMV-specific T cells generally acquire CD57 and CD45RA expression but lack CD28 and CCR7 expression $\left(\mathrm{CD} 45 \mathrm{RA}^{+} \mathrm{CD} 7^{+} \mathrm{CD} 28^{-} \mathrm{CCR}^{-}\right.$) (Gamadia et al., 2001; Appay et al., 2002; Kuijpers et al., 2003). It is widely accepted that late-stage differentiated $\mathrm{CD} 28^{-} \mathrm{T}$ cells are a major characteristic of $\mathrm{T}$ cell aging, suggesting that persistent HCMV infection is associated with immunosenescence. This is further supported by the fact that the large population of HCMVspecific $\mathrm{CD}^{+} \mathrm{CD} 28^{-} \mathrm{T}_{\mathrm{EM}}$ cells that usually accumulate during HCMV persistence are absent in HCMV-seronegative elderly individuals, even those infected with other persistent herpes viruses (Chidrawar et al., 2009; Derhovanessian et al., 2010). Several studies have shown that acute viral infections generate polyfunctional memory $\mathrm{CD} 8^{+} \mathrm{T}$ cells with re-expressed CD45RA (Precopio et al., 2007; Miller et al., 2008; Akondy et al., 2009). Live yellow fever vaccine (YF-17D)-specific memory $\mathrm{CD}^{+}$ $\mathrm{T}$ cells exhibited a terminally differentiated CD45RA ${ }^{+} \mathrm{CCR}^{-}$ phenotype but remained polyfunctional with robust proliferative potential 5-10 years post vaccination, which may suggest that reexpressed CD45RA biomarks highly functional memory $\mathrm{T}$ cells after acute viral infections rather than senescent $\mathrm{T}$ cells (Akondy et al., 2009). However, these YF-17D-specific memory cells were not "true" late-stage differentiated CD28- $\mathrm{T}$ cell subsets but $\mathrm{CD} 27^{+} \mathrm{CD} 28^{+}$cells. Therefore, the use of CD45RA alone as a marker of $\mathrm{T}$ cell differentiation and function is questionable. In fact, the $\mathrm{CD} 45 \mathrm{RA}^{+} \mathrm{CCR}^{-} \mathrm{CD}^{+}$subtype represented resting memory $\mathrm{T}$ cells that could be re-activated upon antigenic stimulation. It has also been shown that CD45RA re-expression on memory $\mathrm{T}$ cells can occur in the absence of further antigenic stimulation, which is indicative of the time elapsed since previous viral infection rather than the functional potential of $\mathrm{CD}^{+}$

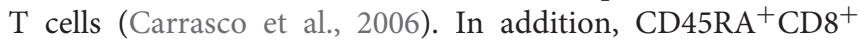
memory $\mathrm{T}$ cells did not accumulate with age and showed no correlation with the $\mathrm{CD} 28^{-} \mathrm{CD}^{+} \mathrm{T}_{\mathrm{EM}}$ subset (Mahnke et al., 2013). Thus, CD28 is a more reliable surface marker for the phenotypic and functional definition of human $\mathrm{T}$ cell differentiation. In contrast to age-dependent $\mathrm{T}$ cell senescence, increased $\mathrm{HCMV}$-specific memory $\mathrm{CD}^{+}$profiles (up to $10 \%$ of the total $\mathrm{CD}^{+} \mathrm{T}$ cell memory pool) were observed even in young hosts, suggesting that progressive clonal expansion may lead to immunosenescence at an earlier age in HCMVinfected individuals (Khan et al., 2004; Chidrawar et al., 2009). However, the high frequency of HCMV-responsive T cells may be a "necessary evil" to restrain HCMV re-activation and maintain control of latent HCMV throughout life (Pawelec, 2005).

There is increasing evidence to suggest that memory inflation in HCMV infection is associated with impaired T cell immunity in elderly hosts. Despite the $\mathrm{CD}^{+} \mathrm{T}$ cell repertoire being diverse enough to recognize different viral epitopes soon after primary HCMV infection, clonal diversity starts to shrink with age, with a large proportion of the repertoire limited to a few high-avidity clones with a replicative senescent phenotype (Day et al., 2007). In particular, T cell responses specific to an individual immunodominant HCMV epitope [such as $65 \mathrm{kDa}$ phosphoprotein (p65) and $55 \mathrm{kDa}$ IE protein 1 (IE1)] can comprise over $25 \%$ of the total $\mathrm{CD}^{+} \mathrm{T}$ cell population in elderly individuals (Khan et al., 2002; Sylwester et al., 2005). Thus, the excess expansion of a single HCMV-specific repertoire in memory inflation may compromise immune protection in response to novel and vaccine antigens by decreasing TCR diversity in the elderly. This renders individuals with only limited virus-specific $\mathrm{T}$ cell clones at risk of life-threatening diseases as they get older (Klenerman and Oxenius, 2016). Additionally, memory inflation in latent HCMV infection may also impact the balance between Th1 and Th2 cytokine production by $\mathrm{CD}^{+} \mathrm{T}$ cells in aged individuals, shifting it in favor of Th1 responses (Saurwein-Teissl et al., 2002; Pawelec et al., 2005). Most inflationary memory $\mathrm{CD}^{+}{ }^{+} \mathrm{T}$ cells are IFN $\gamma$-producing Th1 cells, which might explain the poor antibody-mediated immune responses seen in the elderly (Rentenaar et al., 2000; Bitmansour et al., 2002; van Leeuwen et al., 2006). Indeed, HCMV-specific $\mathrm{CD}^{+}{ }^{+} \mathrm{T}$ cells were negatively associated with humoral responses to influenza vaccination (Derhovanessian et al., 2013). However, the precise mechanism underlying memory inflation is not fully understood, the current hypothesis being that continuous repetitive antigen exposure during latent $\mathrm{HCMV}$ infection contributes to immune system reshaping and enhances the agerelated changes in $\mathrm{T}$ cell compartments in older adults (Pawelec et al., 2009; O'Hara et al., 2012).

Decreased levels of naïve $\mathrm{T}$ cells are also a hallmark of immunosenescence. Several cross-sectional studies have indicated that HCMV has much less of an impact on the naïve $\mathrm{T}$ cell pool than on memory $\mathrm{T}$ cells (Mekker et al., 2012; Wertheimer et al., 2014), but HCMV status is significantly associated with changes in naïve $\mathrm{CD}^{+}{ }^{+} \mathrm{T}$ cells (Wertheimer et al., 2014). Lower levels of naïve $\mathrm{CD}^{+} \mathrm{T}$ cells appear to 


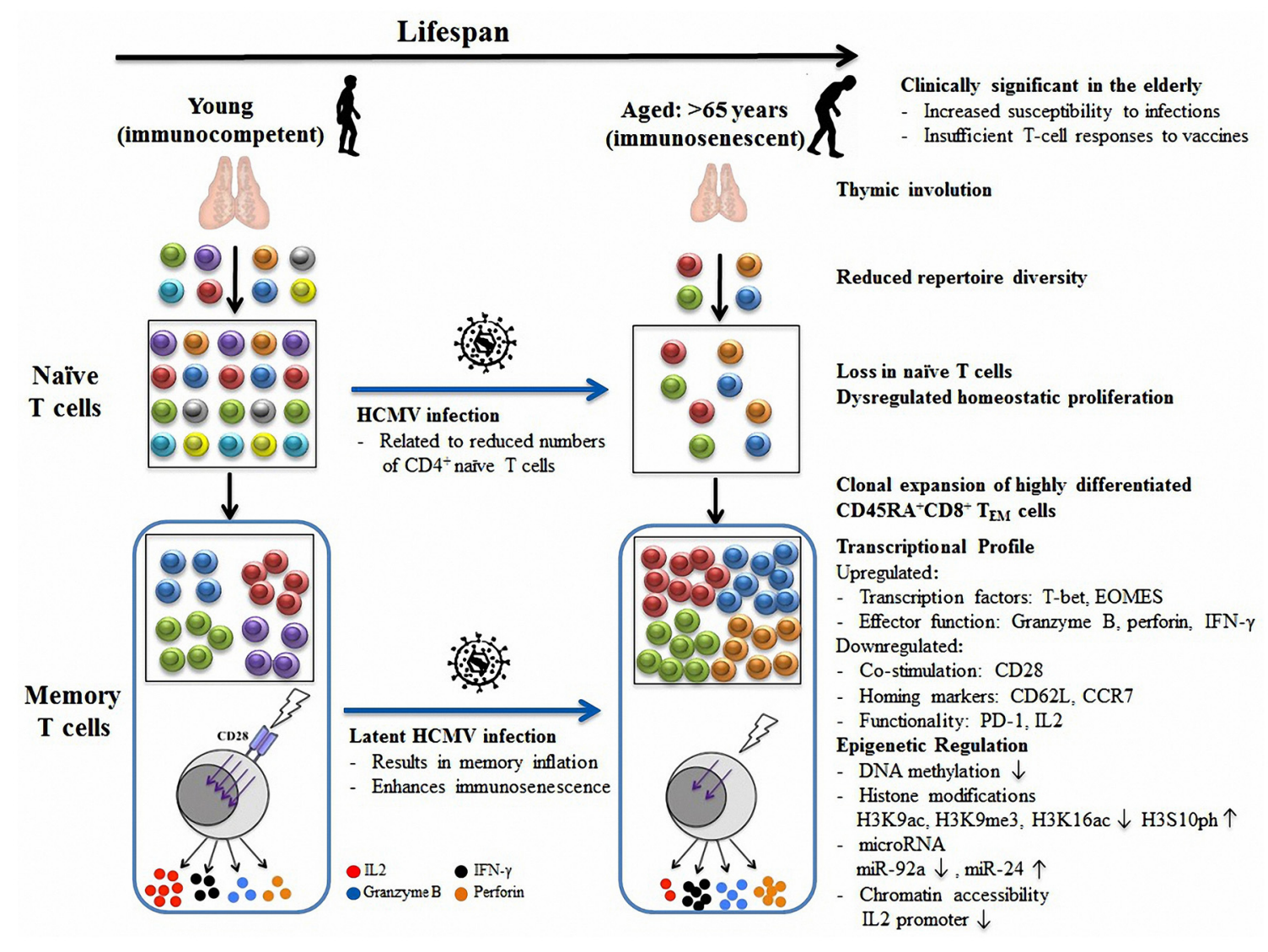

FIGURE 1 | Model of age- and HCMV-related immunosenescence. Thymic involution contributes to reduced naïve T cell export and T cell diversity with age. To compensate for inadequate thymic export, existing naïv T cells increase homeostatic turnover. Upon antigen stimulation, a large number of terminally differentiated CD45RA ${ }^{+} \mathrm{CD}^{+}{ }^{+}$TEM cells clonally expand in the elderly, which dominate the memory pool and further restrict repertoire diversity. These senescent CD45RA ${ }^{+}$ memory $T$ cells typically have diminished $T$ cell responses to stimulation in the absence of CD28 co-stimulatory signaling pathways and are characterized by a variety of altered transcriptional profiles which are epigenetically regulated (including by DNA methylation, histone modifications, microRNAs, and chromatin remodeling). In addition, $\mathrm{HCMV}$ infection can result in $\mathrm{CD}_{4}^{+}$naïve pool depletion and memory inflation, which further accelerate immunosenescence in aged individuals. Together, age and HCMV infection contribute to the overall decline in immune function decline and impair the T cell response to vaccines in the elderly.

be HCMV-seropositivity dependent rather than age related, suggesting differential effects of aging and HCMV infection on T cell subsets (Wertheimer et al., 2014).

The "immune risk profile" (IRP) was developed as part of a longitudinal study to predict mortality and morbidity in the aged (Wikby et al., 2005, 2008). HCMV seropositivity was identified as one of the immune parameters of the IRP, which also included an inverted $\mathrm{CD} 4 / \mathrm{CD} 8$ ratio, accumulation of $\mathrm{CD} 8^{+} \mathrm{CD} 28^{-} \mathrm{T}$ cells, and a lower proportion of naïve cells. However, HCMV infection was detected in very old people, compatible with the extended lifespan observed in studies of individuals at extreme old age in Japan. Plasma HCMV titers were not inversely correlated with the proportion of $\mathrm{CD} 28^{+} \mathrm{T}$ cells in (semi-)supercentenarians (105 years or older), suggesting that HCMV titers might not be a powerful predictor of $\mathrm{T}$ cell senescence in successful aging (Arai et al., 2015). Therefore, it remains controversial whether prediction of mortality can be used as a direct indicator of immunosenescence.

Even though pronounced memory inflation is thought to result in the accumulation of dysfunctional CMV-specific $\mathrm{T}$ cells, several studies have shown that HCMV-specific CD8 ${ }^{+}$ $\mathrm{T}$ cells are polyfunctional in young and middle-aged hosts and can produce multiple cytokines and induce strong effector immune responses to staphylococcal enterotoxin B (SEB) (Solana et al., 2012a; Pera et al., 2014; Sansoni et al., 2014; Hassouneh et al., 2016). With increasing age, T cell exhaustion, another form of $\mathrm{T}$ cell dysfunction, can arise during chronic viral infections, such as with HIV, in which $\mathrm{T}$ cells are constantly stimulated by highly replicating viruses (Wherry, 2011). Typically, exhausted T cells fail to control viral infection as they have effector defects (Wherry, 2011) including loss of proliferative potential, decreased cytotoxicity, impaired ability to secrete cytokines (Frebel et al., 2010; Wherry and Kurachi, 2015), and sustained high expression of several inhibitory receptors (e.g., PD1, KLRG1, and CD57) (Blackburn et al., 2009). Although HCMV-specific $\mathrm{CD} 8^{+}$T cells also have low proliferative capacity and express senescence markers, such as KLRG1 and CD57 (Vieira Braga et al., 2015), they are not exhausted as they are still highly cytotoxic and produce Th1 cytokines in response to sporadic viral re-activation (Klenerman 
and Oxenius, 2016). In addition, molecular profiling of HCMVspecific $\mathrm{CD}^{+} \mathrm{T}$ cells has demonstrated that PD-1, an inhibitory receptor associated with $\mathrm{T}$ cell dysfunction, is expressed at very low levels in healthy individuals (Vieira Braga et al., 2015). Therefore, persistent HCMV infection does not induce massive exhaustion of the $\mathrm{T}$ cell repertoire in most immunocompetent individuals. Indeed, HCMV is rarely reported in elderly individuals, suggesting HCMV-specific $\mathrm{T}$ cells may be able to control pathological HCMV re-activation during healthy aging. However, the possibility remains that HCMV infection can eventually drive the functional exhaustion of $\mathrm{T}$ cells and their extensive accumulation may accelerate immunosenescence in immunocompromised and immunosuppressed individuals (Papagno et al., 2004; Chou and Effros, 2013; Effros, 2016).

Taken together, HCMV infection in the elderly is implicated in immunosenescence and might have a deleterious impact on host immunity and enhance the aging process. Nevertheless, there remains considerable uncertainty regarding the causative role of CMV in immunosenescence. Although it is wellknown that HCMV is a common cause of severe morbidity and mortality in immunocompromised individuals (Reeves and Sinclair, 2008), we cannot exclude the possibility that HCMV might improve the polyfunctionality of $\mathrm{CD}^{+} \mathrm{T}$ cells and consequently benefit the host immune system, at least in young healthy individuals. Moreover, it is still unclear whether HCMV re-activation occurs more frequently in the elderly than in younger individuals. Hence, whether expansion of HCMVspecific $\mathrm{CD}^{+} \mathrm{T}$ cells over time is really deleterious in old age remains unknown. It also remains to be seen to what extent accumulated dysfunctional inflationary memory $\mathrm{T}$ cells cause immunosenescence and how deleterious these cells are on other immune components, such as B cells, $\gamma \delta \mathrm{T}$ cells, and NK cells. Finally, the host immune system might inefficiently control latent HCMV reinfection during aging, thereby allowing the large-scale expansion of virus-specific T-cell clones and further enhancing the immunosenescent profile (Klenerman and Oxenius, 2016; Weltevrede et al., 2016). Thus, both HCMV status and HCMV control must be taken into account in future studies on immune aging.

\section{VACCINATION IN THE ELDERLY}

Vaccination is the most cost-effective and efficient strategy for improving immune responses and protecting humans from infections and other emerging diseases. However, both the efficacy and effectiveness of vaccination decrease in the elderly (Jefferson et al., 2005; Chen et al., 2009; Boraschi and Italiani, 2014; Haussig et al., 2014). Given the rapidly aging population in both developed and developing countries, improving vaccination efficacy to promote healthy aging is a priority, not only for individual well-being, but also for public health.

In the aged population, infectious diseases are a major cause of morbidity and mortality, mainly because the host immune system cannot generate adequate adaptive immune responses to infections (Chen et al., 2009). As discussed above, aging and latent CMV infection are closely associated with immunosenescence by reshaping the host immune repertoire. This can lead to increased susceptibility to severe infections due to the progressive impairment of innate and adaptive immunity in the elderly. In particular, significantly decreased levels of naïve $\mathrm{T}$ cells with a restricted TCR repertoire and expansion of highly differentiated memory $\mathrm{T}$ cells that gradually polarize to a specific virus can compromise host immune responses to novel virus vaccine antigens, leading to suboptimal vaccination. In addition, impaired immune responses accompanied by repetitive antigen exposure can result in chronic inflammation in the elderly and are thought to contribute to the defective immune response to vaccination by further enhancing immunosenescence (Franceschi et al., 2000; Freund et al., 2010; Solana et al., 2012b). Therefore, a more advanced understanding of both the cellular and molecular basis of immunosenescence is required to develop efficient vaccinations that better protect elderly individuals from infections and age-related diseases.

\section{CONCLUSIONS AND PERSPECTIVE}

The adaptive immune system protects the host from numerous pathogens over the course of human life. However, aging is associated with a quantitative decline in immunity, particularly in $\mathrm{T}$ cells, referred to as immunosenescence. Age-related $\mathrm{T}$ cell senescence has been attributed to thymic involution, contraction in the $\mathrm{T}$ cell repertoire, and accumulation of highly differentiated $\mathrm{CD}_{2} 8^{-} \mathrm{T}$ cells. There is growing evidence that latent HCMV infection might accelerate immunosenescence since it causes similar detrimental effects on $\mathrm{T}$ cell phenotype and function to those found in age-associated immunological defects. Thus, age-related and HCMV-related immunosenescence either together or separately - might contribute to increased susceptibility to infectious disease and impaired immune responses to vaccination in the elderly (Figure 1). To prevent severe infections and promote healthy aging, efforts have been made to improve the efficacy of vaccination in the elderly including increased vaccine doses, prime-boost immunization strategies, and the use of adjuvants (Couch et al., 2007; Brown, 2010; Khurana et al., 2011; Dorrington and Bowdish, 2013). Unfortunately, these approaches have yet to significantly improve vaccination outcomes in the older population.

There is also a considerable body of evidence to suggest that epigenetic changes play a crucial role in natural and pathological immune aging (Grolleau-Julius et al., 2009) and a variety of human diseases (Barros and Offenbacher, 2009; Hewagama and Richardson, 2009; Invernizzi, 2009; Wells, 2009). Our unpublished preliminary data suggest that the chromatin accessibility status of certain regulatory elements, in particular that of IL-2, alter over the human lifespan in naïve and memory $\mathrm{T}$ cells. This is further supported by findings that epigenetic regulation plays a prominent role in immune responses and age-related differential gene expression of IL-2 (Bruniquel and Schwartz, 2003) and IFN- $\gamma$ (Yano et al., 2003). A sound knowledge of age-dependent epigenetic gene regulation is essential for optimizing vaccination, perhaps by therapeutically restoring immune function in the elderly. Furthermore, given the 
crucial role of HCMV in host immune function during aging, an increased understanding of the impact of latent HCMV infection on epigenetic signatures across regulatory elements might provide a novel avenue for overcoming immune defects and improving vaccine efficiency in the elderly. Integrating cellular and epigenetic insights of immunology and virology during aging is essential for the development of age-targeted vaccines and age-dependent immunotherapies that exploit sustained memory responses to pathogens.

\section{REFERENCES}

Akondy, R. S., Monson, N. D., Miller, J. D., Edupuganti, S., Teuwen, D., $\mathrm{Wu}, \mathrm{H}$., et al. (2009). The yellow fever virus vaccine induces a broad and polyfunctional human memory $\mathrm{CD}^{+} \mathrm{T}$ cell response. J. Immunol. 183, 7919-7930. doi: 10.4049/jimmunol.0803903

Almanzar, G., Schwaiger, S., Jenewein, B., Keller, M., Herndler-Brandstetter, D., Würzner, R., et al. (2005). Long-term cytomegalovirus infection leads to significant changes in the composition of the $\mathrm{CD} 8^{+} \mathrm{T}$-cell repertoire, which may be the basis for an imbalance in the cytokine production profile in elderly persons. J. Virol. 79, 3675-3683. doi: 10.1128/JVI.79.6.3675-3683.2005

Alonso Arias, R., Moro-García, M. A., Echeverría, A., Solano-Jaurrieta, J. J., SuárezGarcía, F. M., and López-Larrea, C. (2013). Intensity of the humoral response to cytomegalovirus is associated with the phenotypic and functional status of the immune system. J. Virol. 87, 4486-4495. doi: 10.1128/JVI.02425-12

Angelosanto, J. M., and Wherry, E. J. (2010). Transcription factor regulation of $\mathrm{CD}^{+}$T-cell memory and exhaustion. Immunol. Rev. 236, 167-175. doi: 10.1111/j.1600-065X.2010.00927.x

Appay, V., Dunbar, P. R., Callan, M., Klenerman, P., Gillespie, G. M. A., Papagno, L., et al. (2002). Memory $\mathrm{CD}^{+} \mathrm{T}$ cells vary in differentiation phenotype in different persistent virus infections. Nat. Med. 8, 379-385. doi: 10.1038/nm0402-379

Arai, Y., Martin-Ruiz, C. M., Takayama, M., Abe, Y., Takebayashi, T., Koyasu, S., et al. (2015). Inflammation, but not telomere length, predicts successful ageing at extreme old age: a longitudinal study of semi-supercentenarians. EBioMedicine 2, 1549-1558. doi: 10.1016/j.ebiom.2015.07.029

Araki, K., Turner, A. P., Shaffer, V. O., Gangappa, S., Keller, S. A., Bachmann, M. F., et al. (2009). mTOR regulates memory CD8 T-cell differentiation. Nature 460, 108-112. doi: 10.1038/nature08155

Arens, R., Remmerswaal, E. B. M., Bosch, J. A., and van Lier, R. A. W. (2015). 5th International workshop on CMV and immunosenescence - A shadow of cytomegalovirus infection on immunological memory. Eur. J. Immunol. 45, 954-957. doi: 10.1002/eji.201570044

Banerjee, A., Gordon, S. M., Intlekofer, A. M., Paley, M. A., Mooney, E. C., Lindsten, T., et al. (2010). Cutting edge: the transcription factor eomesodermin enables CD8 ${ }^{+} \mathrm{T}$ cells to compete for the memory cell niche. J. Immunol. 185, 4988-4992. doi: 10.4049/jimmunol.1002042

Barros, S. P., and Offenbacher, S. (2009). Epigenetics: connecting environment and genotype to phenotype and disease. J. Dent. Res. 88, 400-408. doi: $10.1177 / 0022034509335868$

Bitmansour, A. D., Douek, D. C., Maino, V. C., and Picker, L. J. (2002). Direct ex vivo analysis of human $\mathrm{CD}^{+}$memory $\mathrm{T}$ cell activation requirements at the single clonotype level. J. Immunol. 169, 1207-1218. doi: 10.4049/jimmunol.169.3.1207

Blackburn, S. D., Shin, H., Haining, W. N., Zou, T., Workman, C. J., Polley, A., et al. (2009). Coregulation of $\mathrm{CD}^{+} \mathrm{T}$ cell exhaustion during chronic viral infection by multiple inhibitory receptors. Nat. Immunol. 10, 29-37. doi: 10.1038/ni.1679

Bollati, V., Schwartz, J., Wright, R., Litonjua, A., Tarantini, L., Suh, H., et al. (2009). Decline in genomic DNA methylation through aging in a cohort of elderly subjects. Mech. Ageing Dev. 130, 234-239. doi: 10.1016/j.mad.2008.12.003

Boraschi, D., and Italiani, P. (2014). Immunosenescence and vaccine failure in the elderly: strategies for improving response. Immunol. Lett. 162, 346-353. doi: 10.1016/j.imlet.2014.06.006

\section{AUTHOR CONTRIBUTIONS}

WT participated in drafting the article. SR helped to revise and edit the manuscript and acted as corresponding author.

\section{ACKNOWLEDGMENTS}

NHMRC funding GNT 1105747. Uncovering the epigenetic landscape that regulates human transcriptional memory.

Boyd, A., Almeida, J. R., Darrah, P. A., Sauce, D., Seder, R. A., Appay, V., et al. (2015). Pathogen-specific $T$ cell polyfunctionality is a correlate of $\mathrm{T}$ cell efficacy and immune protection. PLoS ONE 10:e0128714. doi: 10.1371/journal.pone.0128714

Britanova, O. V., Putintseva, E. V., Shugay, M., Merzlyak, E. M., Turchaninova, M. A., Staroverov, D. B., et al. (2014). Age-related decrease in TCR repertoire diversity measured with deep and normalized sequence profiling. J. Immunol. 192, 2689-2698. doi: 10.4049/jimmunol.1302064

Brown, L. E. (2010). The role of adjuvants in vaccines for seasonal and pandemic influenza. Vaccine 28, 8043-8045. doi: 10.1016/j.vaccine.2010.09.024

Brown, N. F., Stefanovic-Racic, M., Sipula, I. J., and Perdomo, G. (2007). The mammalian target of rapamycin regulates lipid metabolism in primary cultures of rat hepatocytes. Metab. Clin. Exp. 56, 1500-1507. doi: 10.1016/j.metabol.2007.06.016

Bruniquel, D., and Schwartz, R. H. (2003). Selective, stable demethylation of the interleukin-2 gene enhances transcription by an active process. Nat. Immunol. 4, 235-240. doi: 10.1038/ni887

Brunner, S., Herndler-Brandstetter, D., Arnold, C. R., Wiegers, G. J., Villunger, A., Hackl, M., et al. (2012). Upregulation of miR-24 is associated with a decreased DNA damage response upon etoposide treatment in highly differentiated $\mathrm{CD}^{+} \mathrm{T}$ cells sensitizing them to apoptotic cell death. Aging Cell 11, 579-587. doi: 10.1111/j.1474-9726.2012.00819.x

Cambier, J. (2005). Immunosenescence: a problem of lymphopoiesis, homeostasis, microenvironment, and signaling. Immunol. Rev. 205, 5-6. doi: 10.1111/j.0105-2896.2005.00276.x

Cannon, M. J. (2009). Congenital cytomegalovirus (CMV) epidemiology and awareness. J. Clin. Virol. 46(Suppl. 4), S6-S10. doi: 10.1016/j.jcv.2009.09.002

Cannon, M. J., Schmid, D. S., and Hyde, T. B. (2010). Review of cytomegalovirus seroprevalence and demographic characteristics associated with infection. Rev. Med. Virol. 20, 202-213. doi: 10.1002/rmv.655

Carrasco, J., Godelaine, D., Pel, A. V., Boon, T., and van der Bruggen, P. (2006). CD45RA on human CD8 $\mathrm{T}$ cells is sensitive to the time elapsed since the last antigenic stimulation. Blood 108, 2897-2905. doi: 10.1182/blood-2005-11-007237

Chang, C.-H., Curtis, J. D., Maggi, L. B., Faubert, B., Villarino, A. V., O’Sullivan, D., et al. (2013). Posttranscriptional control of T Cell effector function by aerobic glycolysis. Cell 153, 1239-1251. doi: 10.1016/j.cell.2013.05.016

Chen, G., Lustig, A., and Weng, N. (2013). T cell aging: a review of the transcriptional changes determined from genome-wide analysis. Front. Immunol. 4:212. doi: 10.3389/fimmu.2013.00121

Chen, W. H., Kozlovsky, B. F., Effros, R. B., Grubeck-Loebenstein, B., Edelman, R., and Sztein, M. B. (2009). Vaccination in the elderly: an immunological perspective. Trends Immunol. 30, 351-359. doi: 10.1016/j.it.2009.05.002

Chidrawar, S., Khan, N., Wei, W., McLarnon, A., Smith, N., Nayak, L., et al. (2009). Cytomegalovirus-seropositivity has a profound influence on the magnitude of major lymphoid subsets within healthy individuals. Clin. Exp. Immunol. 155, 423-432. doi: 10.1111/j.1365-2249.2008.03785.x

Chou, J. P., and Effros, R. B. (2013). T cell replicative senescence in human aging. Curr. Pharm. Des. 19, 1680-1698. doi: 10.2174/1381612811319090016

Clark, R. A. (2015). Resident memory T cells in human health and disease. Sci. Transl. Med. 7, 269rv1-269rv1. doi: 10.1126/scitranslmed.3010641

Couch, R. B., Winokur, P., Brady, R., Belshe, R., Chen, W. H., Cate, T. R., et al. (2007). Safety and immunogenicity of a high dosage 
trivalent influenza vaccine among elderly subjects. Vaccine 25, 7656-7663. doi: 10.1016/j.vaccine.2007.08.042

Czesnikiewicz-Guzik, M., Lee, W.-W., Cui, D., Hiruma, Y., Lamar, D. L., Yang, Z.-Z., et al. (2008). T cell subset-specific susceptibility to aging. Clin. Immunol. 127, 107-118. doi: 10.1016/j.clim.2007.12.002

Day, E. K., Carmichael, A. J., ten Berge, I. J. M., Waller, E. C. P., Sissons, J. G. P., and Wills, M. R. (2007). Rapid $\mathrm{CD}^{+}$T cell repertoire focusing and selection of high-affinity clones into memory following primary infection with a persistent human virus: human cytomegalovirus. J. Immunol. 179, 3203-3213. doi: 10.4049/jimmunol.179.5.3203

Delgoffe, G. M., Kole, T. P., Zheng, Y., Zarek, P. E., Matthews, K. L., Xiao, B., et al. (2009). The mTOR kinase differentially regulates effector and regulatory $\mathrm{T}$ cell lineage commitment. Immunity 30, 832-844. doi: 10.1016/j.immuni.2009.04.014

Derhovanessian, E., Maier, A. B., Beck, R., Jahn, G., Hähnel, K., Slagboom, P. E., et al. (2010). Hallmark features of immunosenescence are absent in familial longevity. J. Immunol. 185, 4618-4624. doi: 10.4049/jimmunol.10 01629

Derhovanessian, E., Theeten, H., Hähnel, K., Van Damme, P., Cools, N., and Pawelec, G. (2013). Cytomegalovirus-associated accumulation of latedifferentiated CD4 T-cells correlates with poor humoral response to influenza vaccination. Vaccine 31, 685-690. doi: 10.1016/j.vaccine.2012.11.041

Desai, B. N., Myers, B. R., and Schreiber, S. L. (2002). FKBP12-rapamycinassociated protein associates with mitochondria and senses osmotic stress via mitochondrial dysfunction. Proc. Natl. Acad. Sci. U.S.A. 99, 4319-4324. doi: $10.1073 /$ pnas. 261702698

Dorrington, M. G., and Bowdish, D. M. E. (2013). Immunosenescence and novel vaccination strategies for the elderly. Front. Immunol. 4:171. doi: 10.3389/fimmu.2013.00171

Effros, R. B. (2016). The silent war of CMV in aging and HIV infection. Mech. Ageing Dev. 158, 46-52. doi: 10.1016/j.mad.2015.09.003

Fann, M., Chiu, W. K., Wood, W. H., Levine, B. L., Becker, K. G., and Weng, N. (2005). Gene expression characteristics of CD28null memory phenotype $\mathrm{CD}^{+} \mathrm{T}$ cells and its implication in T-cell aging. Immunol. Rev. 205, 190-206. doi: 10.1111/j.0105-2896.2005.00262.x

Farber, D. L., Yudanin, N. A., and Restifo, N. P. (2014). Human memory T cells: generation, compartmentalization and homeostasis. Nat. Rev. Immunol. 14, 24-35. doi: 10.1038/nri3567

Fernández-Morera, J. L., Calvanese, V., Rodríguez-Rodero, S., MenéndezTorre, E., and Fraga, M. F. (2010). Epigenetic regulation of the immune system in health and disease. Tissue Antigens 76, 431-439. doi: 10.1111/j.1399-0039.2010.01587.x

Fessler, J., Felber, A., Duftner, C., and Dejaco, C. (2013). The impact of aging on regulatory T-cells. T Cell Biol. 4:231. doi: 10.3389/fimmu.2013.00231

Flavell, R. A., Herndler-Brandstetter, D., and Ishigame, H. (2013). How to define biomarkers of human $\mathrm{T}$ cell aging and immunocompetence? Front. Immunol. 4:136. doi: 10.3389/fimmu.2013.00136

Fowler, K. B., Stagno, S., Pass, R. F., Britt, W. J., Boll, T. J., and Alford, C. A. (1992). The outcome of congenital cytomegalovirus infection in relation to maternal antibody status. N. Engl. J. Med. 326, 663-667. doi: 10.1056/NEJM199203053261003

Franceschi, C., Bonafè, M., and Valensin, S. (2000). Human immunosenescence: the prevailing of innate immunity, the failing of clonotypic immunity, and the filling of immunological space. Vaccine 18, 1717-1720. doi: 10.1016/S0264-410X(99)00513-7

Frebel, H., Richter, K., and Oxenius, A. (2010). How chronic viral infections impact on antigen-specific T-cell responses. Eur. J. Immunol. 40, 654-663. doi: 10.1002/eji.200940102

Freund, A., Orjalo, A. V., Desprez, P.-Y., and Campisi, J. (2010). Inflammatory networks during cellular senescence: causes and consequences. Trends Mol. Med. 16, 238-246. doi: 10.1016/j.molmed.2010.03.003

Fuente, M. D., (2014). "The immune system, a marker and modulator of the rate of aging," in Immunology of Aging, eds A. Massoud and N. Rezaei (Berlin; Heidelberg: Springer), 3-23.

Gamadia, L. E., Remmerswaal, E. B. M., Weel, J. F., Bemelman, F., van Lier, R. A. W., and Ten Berge, I. J. M. (2003). Primary immune responses to human CMV: a critical role for IFN-gamma-producing $\mathrm{CD}^{+}{ }^{+} \mathrm{T}$ cells in protection against CMV disease. Blood 101, 2686-2692. doi: 10.1182/blood-2002-08-2502
Gamadia, L. E., Rentenaar, R. J., Baars, P. A., Remmerswaal, E. B., Surachno, S., Weel, J. F., et al. (2001). Differentiation of cytomegalovirus-specific CD8(+) $\mathrm{T}$ cells in healthy and immunosuppressed virus carriers. Blood 98, 754-761. doi: 10.1182/blood.V98.3.754

Garg, S. K., Delaney, C., Toubai, T., Ghosh, A., Reddy, P., Banerjee, R., et al. (2014). Aging is associated with increased regulatory T-cell function. Aging Cell 13, 441-448. doi: 10.1111/acel.12191

Genini, E., Percivalle, E., Sarasini, A., Revello, M. G., Baldanti, F., and Gerna, G. (2011). Serum antibody response to the $\mathrm{gH} / \mathrm{gL} / \mathrm{pUL} 128-131$ five-protein complex of human cytomegalovirus (HCMV) in primary and reactivated HCMV infections. J. Clin. Virol. 52, 113-118. doi: 10.1016/j.jcv.2011. 06.018

Gerna, G., Sarasini, A., Patrone, M., Percivalle, E., Fiorina, L., Campanini, G., et al. (2008). Human cytomegalovirus serum neutralizing antibodies block virus infection of endothelial/epithelial cells, but not fibroblasts, early during primary infection. J. Gen. Virol. 89, 853-865. doi: 10.1099/vir.0.83523-0

Gibney, E. R., and Nolan, C. M. (2010). Epigenetics and gene expression. Heredity 105, 4-13. doi: 10.1038/hdy.2010.54

Gibson, W. (2008). Structure and formation of the cytomegalovirus virion. Curr. Top. Microbiol. Immunol. 325, 187-204. doi: 10.1007/978-3-540-77349-8_11

Goodrum, F. D., Jordan, C. T., High, K., and Shenk, T. (2002). Human cytomegalovirus gene expression during infection of primary hematopoietic progenitor cells: a model for latency. Proc. Natl. Acad. Sci. U.S.A. 99, 16255-16260. doi: 10.1073/pnas.252630899

Goronzy, J. J., Fang, F., Cavanagh, M. M., Qi, Q., and Weyand, C. M. (2015). Naive T cell maintenance and function in human aging. J. Immunol. 194, 4073-4080. doi: 10.4049/jimmunol.1500046

Grolleau-Julius, A., Ray, D., and Yung, R. L. (2009). The role of epigenetics in aging and autoimmunity. Clin. Rev. Allergy Immunol. 39, 42-50. doi: 10.1007/s12016-009-8169-3

Gubser, P. M., Bantug, G. R., Razik, L., Fischer, M., Dimeloe, S., Hoenger, G., et al. (2013). Rapid effector function of memory $\mathrm{CD}^{+} \mathrm{T}$ cells requires an immediate-early glycolytic switch. Nat. Immunol. 14, 1064-1072. doi: $10.1038 /$ ni.2687

Hahn, G., Jores, R., and Mocarski, E. S. (1998). Cytomegalovirus remains latent in a common precursor of dendritic and myeloid cells. Proc. Natl. Acad. Sci. U. S. A. 95, 3937-3942.

Hammarlund, E., Lewis, M. W., Carter, S. V., Amanna, I., Hansen, S. G., Strelow, L. I., et al. (2005). Multiple diagnostic techniques identify previously vaccinated individuals with protective immunity against monkeypox. Nat. Med. 11, 1005-1011. doi: 10.1038/nm1273

Hammarlund, E., Lewis, M. W., Hansen, S. G., Strelow, L. I., Nelson, J. A., Sexton, G. J., et al. (2003). Duration of antiviral immunity after smallpox vaccination. Nat. Med. 9, 1131-1137. doi: 10.1038/nm917

Hanley, P. J., and Bollard, C. M. (2014). Controlling cytomegalovirus: helping the immune system take the lead. Viruses 6, 2242-2258. doi: 10.3390/v6062242

Hassouneh, F., Campos, C., López-Sejas, N., Alonso, C., Tarazona, R., Solana, R., et al. (2016). Effect of age and latent CMV infection on CD8 ${ }^{+} \mathrm{CD}^{+}{ }^{+} \mathrm{T}$ cells (NKT-like) frequency and functionality. Mech. Ageing Dev. 158, 38-45. doi: 10.1016/j.mad.2015.12.003

Haussig, J. M., Burgold, J., Hafalla, J. C. R., Matuschewski, K., and Kooij, T. W. A. (2014). Signatures of malaria vaccine efficacy in ageing murine immune memory. Parasite Immunol. 36, 199-206. doi: 10.1111/pim. 12104

Haynes, L., Eaton, S. M., Burns, E. M., Randall, T. D., and Swain, S. L. (2003). CD4 $\mathrm{T}$ cell memory derived from young naive cells functions well into old age, but memory generated from aged naive cells functions poorly. Proc. Natl. Acad. Sci. U.S.A. 100, 15053-15058. doi: 10.1073/pnas.2433717100

Henson, S. M., Lanna, A., Riddell, N. E., Franzese, O., Macaulay, R., Griffiths, S. J., et al. (2014). p38 signaling inhibits mTORC1-independent autophagy in senescent human $\mathrm{CD}^{+} \mathrm{T}$ cells. J. Clin. Invest. 124, 4004-4016. doi: 10.1172/JCI75051

Herndler-Brandstetter, D., Landgraf, K., Tzankov, A., Jenewein, B., Brunauer, R., Laschober, G. T., et al. (2012). The impact of aging on memory T cell phenotype and function in the human bone marrow. J. Leukoc. Biol. 91, 197-205. doi: 10.1189/jlb.0611299

Hewagama, A., and Richardson, B. (2009). The genetics and epigenetics of autoimmune diseases. J. Autoimmun. 33, 3-11. doi: 10.1016/j.jaut.2009.03.007 
Heyn, H., Li, N., Ferreira, H. J., Moran, S., Pisano, D. G., Gomez, A., et al. (2012). Distinct DNA methylomes of newborns and centenarians. Proc. Natl. Acad. Sci. U.S.A. 109, 10522-10527. doi: 10.1073/pnas.1120658109

Hongdong, L., Guini, H., and Zheng, G. (2015). [Age-related DNA methylation changes in peripheral whole blood]. Yi Chuan 37, 165-173. doi: 10.16288/j.yczz.14-394

Huang, M.-C., Liao, J.-J., Bonasera, S., Longo, D. L., and Goetzl, E. J. (2008), Nuclear factor- $\kappa \mathrm{B}$-dependent reversal of aging-induced alterations in $\mathrm{T}$ cell cytokines. FASEB J. 22, 2142-2150. doi: 10.1096/fj.07-103721

Invernizzi, P. (2009). Future directions in genetic for autoimmune diseases. J. Autoimmun. 33, 1-2. doi: 10.1016/j.jaut.2009.03.001

Jackson, S. E., Mason, G. M., and Wills, M. R. (2011). Human cytomegalovirus immunity and immune evasion. Virus Res. 157, 151-160. doi: 10.1016/j.virusres.2010.10.031

Jacomet, F., Cayssials, E., Basbous, S., Levescot, A., Piccirilli, N., Desmier, D., et al. (2015). Evidence for eomesodermin-expressing innate-like CD8 ${ }^{+}$ KIR/NKG2A $+\mathrm{T}$ cells in human adults and cord blood samples. Eur. J. Immunol. 45, 1926-1933. doi: 10.1002/eji.201545539

Jefferson, T., Rivetti, D., Rivetti, A., Rudin, M., Di Pietrantonj, C., and Demicheli, V. (2005). Efficacy and effectiveness of influenza vaccines in elderly people: a systematic review. Lancet Lond. Engl. 366, 1165-1174. doi: 10.1016/S0140-6736(05)67339-4

Jones, R. G., and Thompson, C. B. (2007). Revving the engine: signal transduction fuels $\mathrm{T}$ cell activation. Immunity 27, 173-178. doi: 10.1016/j.immuni.2007.07.008

Joshi, N. S., Cui, W., Dominguez, C. X., Chen, J. H., Hand, T. W., and Kaech, S. M. (2011). Increased numbers of preexisting memory CD8 T cells and decreased T-bet expression can restrain terminal differentiation of secondary effector and memory CD8 T cells. J. Immunol. 187, 4068-4076. doi: 10.4049/jimmunol.1002145

Karrer, U., Sierro, S., Wagner, M., Oxenius, A., Hengel, H., Koszinowski, U. H., et al. (2003). Memory inflation: continuous accumulation of antiviral CD8 ${ }^{+}$ T cells over time. J. Immunol. 170, 2022-2029. doi: 10.4049/jimmunol.170. 4.2022

Kawakami, K., Nakamura, A., Ishigami, A., Goto, S., and Takahashi, R. (2008). Age-related difference of site-specific histone modifications in rat liver. Biogerontology 10, 415-421. doi: 10.1007/s10522-008-9176-0

Khan, N., Hislop, A., Gudgeon, N., Cobbold, M., Khanna, R., Nayak, L., et al. (2004). Herpesvirus-specific CD8 T cell immunity in old age: cytomegalovirus impairs the response to a coresident EBV infection. J. Immunol. 173, 7481-7489. doi: 10.4049/jimmunol.173.12.7481

Khan, N., Shariff, N., Cobbold, M., Bruton, R., Ainsworth, J. A., Sinclair, A. J., et al. (2002). Cytomegalovirus seropositivity drives the CD8 T cell repertoire toward greater clonality in healthy elderly individuals. J. Immunol. 169, 1984-1992. doi: 10.4049/jimmunol.169.4.1984

Khurana, S., Verma, N., Yewdell, J. W., Hilbert, A. K., Castellino, F., Lattanzi, M., et al. (2011). MF59 adjuvant enhances diversity and affinity of antibodymediated immune response to pandemic influenza vaccines. Sci. Transl. Med. 3, 85ra48. doi: 10.1126/scitranslmed.3002336

Klenerman, P., and Oxenius, A. (2016). T cell responses to cytomegalovirus. Nat. Rev. Immunol. 16, 367-377. doi: 10.1038/nri.2016.38

Koch, S., Larbi, A., Derhovanessian, E., Özcelik, D., Naumova, E., and Pawelec, G. (2008). Multiparameter flow cytometric analysis of CD4 and CD8 T cell subsets in young and old people. Immun. Ageing 5:6. doi: 10.1186/17424933-5-6

Koch, S., Larbi, A., Ozcelik, D., Solana, R., Gouttefangeas, C., Attig, S., et al. (2007). Cytomegalovirus infection: a driving force in human $\mathrm{T}$ cell immunosenescence. Ann. N. Y. Acad. Sci. 1114, 23-35. doi: 10.1196/annals.1396.043

Kouzarides, T. (2007). Chromatin modifications and their function. Cell 128, 693-705. doi: 10.1016/j.cell.2007.02.005

Kuijpers, T. W., Vossen, M. T., Gent, M.-R., Davin, J.-C., Roos, M. T., Wertheim-van Dillen, P. M., et al. (2003). Frequencies of circulating cytolytic, $\mathrm{CD}_{5} \mathrm{RA}^{+} \mathrm{CD}^{2} 7^{-}, \mathrm{CD}^{+}{ }^{+} \mathrm{T}$ lymphocytes depend on infection with CMV. J. Immunol. 170, 4342-4348. doi: 10.4049/jimmunol.170.8.4342

Kundu, S., and Peterson, C. L. (2009). Role of chromatin states in transcriptional memory. Biochim. Biophys. Acta (BBA) - Gen. Subj. 1790, 445-455. doi: 10. 1016/j.bbagen.2009.02.009
Lazarevic, V., Glimcher, L. H., and Lord, G. M. (2013). T-bet: a bridge between innate and adaptive immunity. Nat. Rev. Immunol. 13, 777-789. doi: $10.1038 /$ nri3536

Lazuardi, L., Jenewein, B., Wolf, A. M., Pfister, G., Tzankov, A., and GrubeckLoebenstein, B. (2005). Age-related loss of naïve T cells and dysregulation of T-cell/B-cell interactions in human lymph nodes. Immunology 114, 37-43. doi: 10.1111/j.1365-2567.2004.02006.x

Lee, J. S., Lee, W.-W., Kim, S. H., Kang, Y., Lee, N., Shin, M. S., et al. (2011). Ageassociated alteration in naive and memory Th17 cell response in humans. Clin. Immunol. 140, 84-91. doi: 10.1016/j.clim.2011.03.018

Lesourd, B. M., Mazari, L., and Ferry, M. (1998). The role of nutrition in immunity in the aged. Nutr. Rev. 56, S113-S125.

Li, G., Yu, M., Lee, W.-W., Tsang, M., Krishnan, E., Weyand, C. M., et al. (2012). Decline in miR-181a expression with age impairs $\mathrm{T}$ cell receptor sensitivity by increasing DUSP6 activity. Nat. Med. 18, 1518-1524. doi: 10.1038/nm.2963

Li, H., Margolick, J. B., Bream, J. H., Nilles, T. L., Langan, S., Bui, H. T., et al. (2014). Heterogeneity of $\mathrm{CD} 4^{+}$and $\mathrm{CD} 8^{+} \mathrm{T}$-cell responses to cytomegalovirus in HIV-infected and HIV-uninfected men who have sex with men. J. Infect. Dis. 210, 400-404. doi: 10.1093/infdis/jiu093

Li, Q.-J., Chau, J., Ebert, P. J. R., Sylvester, G., Min, H., Liu, G., et al. (2007). miR-181a is an intrinsic modulator of T cell sensitivity and selection. Cell 129, 147-161. doi: 10.1016/j.cell.2007.03.008

Lim, M.-A., Lee, J., Park, J.-S., Jhun, J.-Y., Moon, Y.-M., Cho, M.-L., et al. (2014). Increased Th17 differentiation in aged mice is significantly associated with high IL-1 $\beta$ level and low IL-2 expression. Exp. Gerontol. 49, 55-62. doi: 10.1016/j.exger.2013.10.006

Ludwig, A., and Hengel, H. (2009). Epidemiological impact and disease burden of congenital cytomegalovirus infection in Europe. Euro Surveill. 14, 26-32.

Macagno, A., Bernasconi, N. L., Vanzetta, F., Dander, E., Sarasini, A., Revello, M. G., et al. (2010). Isolation of human monoclonal antibodies that potently neutralize human cytomegalovirus infection by targeting different epitopes on the gH/gL/UL128-131A complex. J. Virol. 84, 1005-1013. doi: 10.1128/JVI.01809-09

Mackus, W. J. M., Frakking, F. N. J., Grummels, A., Gamadia, L. E., De Bree, G. J., Hamann, D., et al. (2003). Expansion of CMV-specific $\mathrm{CD}^{+} \mathrm{CD}^{2} 5 \mathrm{RA}^{+} \mathrm{CD}^{-} 7^{-} \mathrm{T}$ cells in B-cell chronic lymphocytic leukemia. Blood 102, 1057-1063. doi: 10.1182/blood-2003-01-0182

Mahnke, Y. D., Brodie, T. M., Sallusto, F., Roederer, M., and Lugli, E. (2013). The who's who of T-cell differentiation: human memory T-cell subsets. Eur. J. Immunol. 43, 2797-2809. doi: 10.1002/eji.201343751

Maijó, M., Clements, S. J., Ivory, K., Nicoletti, C., and Carding, S. R. (2014). Nutrition, diet and immunosenescence. Mech. Ageing Dev. 136-137, 116-128. doi: 10.1016/j.mad.2013.12.003

Mannick, J. B., Giudice, G. D., Lattanzi, M., Valiante, N. M., Praestgaard, J., Huang, B., et al. (2014). mTOR inhibition improves immune function in the elderly. Sci. Transl. Med. 6, 268ra179-268ra179. doi: 10.1126/scitranslmed.30 09892

Mekker, A., Tchang, V. S., Haeberli, L., Oxenius, A., Trkola, A., and Karrer, U. (2012). Immune senescence: relative contributions of age and cytomegalovirus infection. PLoS Pathog. 8:e1002850. doi: 10.1371/journal.ppat.1002850

Miller, J. D., van der Most, R. G., Akondy, R. S., Glidewell, J. T., Albott, S., Masopust, D., et al. (2008). Human effector and memory CD8 ${ }^{+} \mathrm{T}$ Cell responses to smallpox and yellow fever vaccines. Immunity 28, 710-722. doi: 10.1016/j.immuni.2008.02.020

Miller, R. A. (1996). The aging immune system: primer and prospectus. Science 273, 70-74.

Miller, R. A., Buehner, G., Chang, Y., Harper, J. M., Sigler, R., and SmithWheelock, M. (2005). Methionine-deficient diet extends mouse lifespan, slows immune and lens aging, alters glucose, T4, IGF-I and insulin levels, and increases hepatocyte MIF levels and stress resistance. Aging Cell 4, 119-125. doi: 10.1111/j.1474-9726.2005.00152.x

Moro-García, M. A., Alonso-Arias, R., and López-Larrea, C. (2013). When Aging Reaches $\mathrm{CD}^{+}{ }^{+}$T-cells: phenotypic and functional changes. Front. Immunol. 4:107. doi: 10.3389/fimmu.2013.00107

Mueller, S. N., Gebhardt, T., Carbone, F. R., and Heath, W. R. (2013). Memory T cell subsets, migration patterns, and tissue residence. Annu. Rev. Immunol. 31, 137-161. doi: 10.1146/annurev-immunol-032712-095954 
Muthusamy, N., Barton, K., and Leiden, J. M. (1995). Defective activation and survival of T cells lacking the Ets-1 transcription factor. Nature 377, 639-642. doi: 10.1038/377639a0

Naylor, K., Li, G., Vallejo, A. N., Lee, W.-W., Koetz, K., Bryl, E., et al. (2005). The influence of age on T cell generation and TCR diversity. J. Immunol. 174, 7446-7452. doi: 10.4049/jimmunol.174.11.7446

Nikolich-Žugich, J. (2008). Ageing and life-long maintenance of T-cell subsets in the face of latent persistent infections. Nat. Rev. Immunol. 8, 512-522. doi: $10.1038 /$ nri2318

Nikolich-Žugich, J. (2014). Aging of the T cell compartment in mice and humans: from no naïve expectations to foggy memories. J. Immunol. 193, 2622-2629. doi: 10.4049/jimmunol.1401174

Nikolich-Žugich, J., and Rudd, B. D. (2010). Immune memory and aging: an infinite or finite resource? Curr. Opin. Immunol. 22, 535-540. doi: 10.1016/j.coi.2010.06.011

Noriega, V., Redmann, V., Gardner, T., and Tortorella, D. (2012). Diverse immune evasion strategies by human cytomegalovirus. Immunol. Res. 54, 140-151. doi: $10.1007 /$ s12026-012-8304-8

O'Hara, G. A., Welten, S. P. M., Klenerman, P., and Arens, R. (2012). Memory T cell inflation: understanding cause and effect. Trends Immunol. 33, 84-90. doi: 10.1016/j.it.2011.11.005

Ohyashiki, M., Ohyashiki, J. H., Hirota, A., Kobayashi, C., and Ohyashiki, K. (2011). Age-related decrease of miRNA-92a levels in human CD8 ${ }^{+}$T-cells correlates with a reduction of naïve T lymphocytes. Immun. Ageing 8:11. doi: 10.1186/1742-4933-8-11

Pae, M., Meydani, S. N., and Wu, D. (2011). The Role of nutrition in enhancing immunity in aging. Aging Dis. 3, 91-129.

Papagno, L., Spina, C. A., Marchant, A., Salio, M., Rufer, N., Little, S., et al. (2004). Immune activation and $\mathrm{CD}^{+}$T-cell differentiation towards senescence in HIV-1 infection. PLoS Biol. 2:E20. doi: 10.1371/journal.pbio.00 20020

Paulus, C., and Nevels, M. (2009). The human cytomegalovirus major immediateearly proteins as antagonists of intrinsic and innate antiviral host responses. Viruses 1, 760-779. doi: 10.3390/v1030760

Pawelec, G. (2005). Immunosenescence and vaccination. Immun. Ageing 2:16. doi: 10.1186/1742-4933-2-16

Pawelec, G., Akbar, A., Caruso, C., Solana, R., Grubeck-Loebenstein, B., and Wikby, A. (2005). Human immunosenescence: is it infectious? Immunol. Rev. 205, 257-268. doi: 10.1111/j.0105-2896.2005.00271.x

Pawelec, G., Derhovanessian, E., Larbi, A., Strindhall, J., and Wikby, A. (2009). Cytomegalovirus and human immunosenescence. Rev. Med. Virol. 19, 47-56. doi: $10.1002 / \mathrm{rmv} .598$

Peng, T., Golub, T. R., and Sabatini, D. M. (2002). The immunosuppressant rapamycin mimics a starvation-like signal distinct from amino acid and glucose deprivation. Mol. Cell. Biol. 22, 5575-5584. doi: 10.1128/MCB.22.15.5575-5584.2002

Pera, A., Campos, C., Corona, A., Sanchez-Correa, B., Tarazona, R., Larbi, A., et al. (2014). CMV Latent Infection Improves $\mathrm{CD}^{+} \mathrm{T}$ response to SEB due to expansion of polyfunctional $\mathrm{CD}^{+} 7^{+}$cells in young individuals. PLoS ONE 9:e88538. doi: 10.1371/journal.pone.0088538

Polić, B., Hengel, H., Krmpotić, A., Trgovcich, J., Pavić, I., Luccaronin, P., et al. (1998). Hierarchical and redundant lymphocyte subset control precludes cytomegalovirus replication during latent infection. J. Exp. Med. 188, 1047-1054.

Ponnappan, S., and Ponnappan, U. (2011). Aging and immune function: molecular mechanisms to interventions. Antioxid. Redox Signal. 14, 1551-1585. doi: 10.1089/ars.2010.3228

Pourgheysari, B., Khan, N., Best, D., Bruton, R., Nayak, L., and Moss, P. A. H. (2007). The cytomegalovirus-specific $\mathrm{CD} 4^{+}$T-cell response expands with age and markedly alters the $\mathrm{CD} 4^{+}$T-cell repertoire. J. Virol. 81, 7759-7765. doi: 10.1128/JVI.01262-06

Precopio, M. L., Betts, M. R., Parrino, J., Price, D. A., Gostick, E., Ambrozak, D. R., et al. (2007). Immunization with vaccinia virus induces polyfunctional and phenotypically distinctive CD8 ${ }^{+}$T cell responses. J. Exp. Med. 204, 1405-1416. doi: 10.1084 /jem. 20062363

Ramanathan, A., and Schreiber, S. L. (2009). Direct control of mitochondrial function by mTOR. Proc. Natl. Acad. Sci. U.S.A. 106, 22229-22232. doi: 10.1073/pnas.0912074106
Rao, R. R., Li, Q., Odunsi, K., and Shrikant, P. A. (2010). The mTOR kinase determines effector versus memory $\mathrm{CD}^{+} \mathrm{T}$ cell fate by regulating the expression of transcription factors T-bet and eomesodermin. Immunity 32, 67-78. doi: 10.1016/j.immuni.2009.10.010

Reeves, M. B., MacAry, P. A., Lehner, P. J., Sissons, J. G. P., and Sinclair, J. H. (2005). Latency, chromatin remodeling, and reactivation of human cytomegalovirus in the dendritic cells of healthy carriers. Proc. Natl. Acad. Sci. U.S.A. 102, 4140-4145. doi: 10.1073/pnas.0408994102

Reeves, M., and Sinclair, J. (2008). Aspects of human cytomegalovirus latency and reactivation. Curr. Top. Microbiol. Immunol. 325, 297-313. doi: 10.1007/978-3-540-77349-8_17

Renkema, K. R., Li, G., Wu, A., Smithey, M. J., and Nikolich-Žugich, J. (2014). Two separate defects affecting true naive or virtual memory $\mathrm{T}$ cell precursors combine to reduce naive T cell responses with aging. J. Immunol. 192, 151-159. doi: 10.4049/jimmunol.1301453

Rentenaar, R. J., Gamadia, L. E., van DerHoek, N., van Diepen, F. N., Boom, R., Weel, J. F., et al. (2000). Development of virus-specific CD4(+) T cells during primary cytomegalovirus infection. J. Clin. Invest. 105, 541-548. doi: 10.1172/JCI8229

Revello, M. G., and Gerna, G. (2002). Diagnosis and management of human cytomegalovirus infection in the mother, fetus, and newborn infant. Clin. Microbiol. Rev. 15, 680-715. doi: 10.1128/CMR.15.4.680-715.2002

Ron-harel, N., Sharpe, A. H., and Haigis, M. C. (2015). Mitochondrial metabolism in T cell activation and senescence: a mini-review. Gerontology 61, 131-138. doi: $10.1159 / 000362502$

Sallusto, F., Lenig, D., Förster, R., Lipp, M., and Lanzavecchia, A. (1999). Two subsets of memory $\mathrm{T}$ lymphocytes with distinct homing potentials and effector functions. Nature 401, 708-712. doi: 10.1038/44385

Salpea, P., Russanova, V. R., Hirai, T. H., Sourlingas, T. G., Sekeri-Pataryas, K. E., Romero, R., et al. (2012). Postnatal development- and age-related changes in DNA-methylation patterns in the human genome. Nucleic Acids Res. 40, 6477-6494. doi: 10.1093/nar/gks312

Sansoni, P., Vescovini, R., Fagnoni, F., Biasini, C., Zanni, F., Zanlari, L., et al. (2008). The immune system in extreme longevity. Exp. Gerontol. 43, 61-65. doi: 10.1016/j.exger.2007.06.008

Sansoni, P., Vescovini, R., Fagnoni, F. F., Akbar, A., Arens, R., Chiu, Y.-L., et al. (2014). New advances in CMV and immunosenescence. Exp. Gerontol. 55, 54-62. doi: 10.1016/j.exger.2014.03.020

Sathaliyawala, T., Kubota, M., Yudanin, N., Turner, D., Camp, P., Thome, J. J. C., et al. (2013). Distribution and compartmentalization of human circulating and tissue-resident memory T cell subsets. Immunity 38, 187-197. doi: 10.1016/j.immuni.2012.09.020

Saurwein-Teissl, M., Lung, T. L., Marx, F., Gschösser, C., Asch, E., Blasko, I., et al. (2002). Lack of antibody production following immunization in old age: association with $\mathrm{CD} 8^{+} \mathrm{CD} 28^{-} \mathrm{T}$ cell clonal expansions and an imbalance in the production of Th1 and Th2 cytokines. J. Immunol. 168, 5893-5899. doi: 10.4049/jimmunol.168.11.5893

Schleiss, M. R. (2013). Cytomegalovirus in the neonate: immune correlates of infection and protection. Clin. Dev. Immunol. 2013:501801. doi: 10.1155/2013/501801. Available online at: https://www.hindawi.com/ journals/jir/2013/501801/cta/

Shanley, D. P., Aw, D., Manley, N. R., and Palmer, D. B. (2009). An evolutionary perspective on the mechanisms of immunosenescence. Trends Immunol. 30, 374-381. doi: 10.1016/j.it.2009.05.001

Sidler, C., Woycicki, R., Ilnytskyy, Y., Metz, G., Kovalchuk, I., and Kovalchuk, O. (2013). Immunosenescence is associated with altered gene expression and epigenetic regulation in primary and secondary immune organs. Genet. Aging 4:211. doi: 10.3389/fgene.2013.00211

Sinclair, J., and Sissons, P. (2006). Latency and reactivation of human cytomegalovirus. J. Gen. Virol. 87, 1763-1779. doi: 10.1099/vir.0.81891-0

Sipula, I. J., Brown, N. F., and Perdomo, G. (2006). Rapamycin-mediated inhibition of mammalian target of rapamycin in skeletal muscle cells reduces glucose utilization and increases fatty acid oxidation. Metab. Clin. Exp. 55, 1637-1644. doi: 10.1016/j.metabol.2006.08.002

Snyder, L. D., Chan, C., Kwon, D., Yi, J. S., Martissa, J. A., Finlen Copeland, C. A., et al. (2016). Polyfunctional T-cell signatures predict protection from cytomegalovirus after lung transplant. Am. J. Respir. Crit. Care Med. 193, 78-85. doi: $10.1164 / \mathrm{rccm} .201504-0733 \mathrm{OC}$ 
Solana, R., Tarazona, R., Aiello, A. E., Akbar, A. N., Appay, V., Beswick, M., et al. (2012a). CMV and Immunosenescence: from basics to clinics. Immun. Ageing 9:23. doi: $10.1186 / 1742-4933-9-23$

Solana, R., Tarazona, R., Gayoso, I., Lesur, O., Dupuis, G., and Fulop, T. (2012b). Innate immunosenescence: effect of aging on cells and receptors of the innate immune system in humans. Semin. Immunol. 24, 331-341. doi: 10.1016/j.smim.2012.04.008

Sprent, J., and Surh, C. D. (2011). Normal T cell homeostasis: the conversion of naïve cells into memory-phenotype cells. Nat. Immunol. 12, 478-484. doi: $10.1038 /$ ni.2018

Strahl, B. D., and Allis, C. D. (2000). The language of covalent histone modifications. Nature 403, 41-45. doi: 10.1038/47412

Sylwester, A. W., Mitchell, B. L., Edgar, J. B., Taormina, C., Pelte, C., Ruchti, F., et al. (2005). Broadly targeted human cytomegalovirus-specific $\mathrm{CD} 4^{+}$and $\mathrm{CD}^{+}{ }^{+} \mathrm{T}$ cells dominate the memory compartments of exposed subjects. J. Exp. Med. 202, 673-685. doi: 10.1084/jem.20050882

Tesar, B. M., Du, W., Shirali, A., Walker, W. E., Shen, H., and Goldstein, D. R. (2009). Aging augments IL-17 T cell alloimmune responses. Am. J. Transplant. 9, 54-63. doi: 10.1111/j.1600-6143.2008.02458.x

Tserel, L., Kolde, R., Limbach, M., Tretyakov, K., Kasela, S., Kisand, K., et al. (2015). Age-related profiling of DNA methylation in $\mathrm{CD}^{+} \mathrm{T}$ cells reveals changes in immune response and transcriptional regulator genes. Sci. Rep. 5:13107. doi: 10.1038/srep13107. Available online at: http://www.nature.com/articles/ srep 13107

Turner, B. M. (2003). Memorable transcription. Nat. Cell Biol. 5, 390-393. doi: 10. 1038/ncb0503-390

Valkenburg, S. A., Venturi, V., Dang, T. H. Y., Bird, N. L., Doherty, P. C., Turner, S. J., et al. (2012). Early priming minimizes the age-related immune compromise of $\mathrm{CD}^{+} \mathrm{T}$ cell diversity and function. PLoS Pathog. 8:e1002544. doi: 10.1371/journal.ppat.1002544

Van Epps, P., Banks, R., Aung, H., Betts, M. R., and Canaday, D. H. (2014). Agerelated differences in polyfunctional T cell responses. Immun. Ageing 11:14. doi: $10.1186 / 1742-4933-11-14$

van Leeuwen, E. M. M., Remmerswaal, E. B. M., Heemskerk, M. H. M., ten Berge, I. J. M., and van Lier, R. A. W. (2006). Strong selection of virus-specific cytotoxic CD4+ T-cell clones during primary human cytomegalovirus infection. Blood 108, 3121-3127. doi: 10.1182/blood-2006-03-006809

Vieira Braga, F. A., Hertoghs, K. M. L., van Lier, R. A. W., and van Gisbergen, K. P. J. M. (2015). Molecular characterization of HCMV-specific immune responses: parallels between CD8(+) T cells, CD4(+) T cells, and NK cells. Eur. J. Immunol. 45, 2433-2445. doi: 10.1002/eji.201545495

Wang, D., and Shenk, T. (2005). Human cytomegalovirus virion protein complex required for epithelial and endothelial cell tropism. Proc. Natl. Acad. Sci. U.S.A. 102, 18153-18158. doi: 10.1073/pnas.0509201102

Weinberger, B., Herndler-Brandstetter, D., Schwanninger, A., Weiskopf, D., and Grubeck-Loebenstein, B. (2008). Biology of immune responses to vaccines in elderly persons. Clin. Infect. Dis. 46, 1078-1084. doi: 10.1086/529197

Wells, A. D. (2009). New insights into the molecular basis of T cell anergy: anergy factors, avoidance sensors, and epigenetic imprinting. J. Immunol. 182, 7331-7341. doi: 10.4049/jimmunol.0803917

Weltevrede, M., Eilers, R., de Melker, H. E., and van Baarle, D. (2016). Cytomegalovirus persistence and T-cell immunosenescence in people aged fifty and older: a systematic review. Exp. Gerontol. 77, 87-95. doi: 10.1016/j.exger.2016.02.005
Wertheimer, A. M., Bennett, M. S., Park, B., Uhrlaub, J. L., Martinez, C., Pulko, V., et al. (2014). Aging and cytomegalovirus (CMV) infection differentially and jointly affect distinct circulating $\mathrm{T}$ cell subsets in humans. J. Immunol. 192, 2143-2155. doi: 10.4049/jimmunol. 1301721

Wherry, E. J. (2011). T cell exhaustion. Nat. Immunol. 12, 492-499. doi: $10.1038 /$ ni.2035

Wherry, E. J., and Kurachi, M. (2015). Molecular and cellular insights into T cell exhaustion. Nat. Rev. Immunol. 15, 486-499. doi: 10.1038/ nri3862

Wikby, A., Ferguson, F., Forsey, R., Thompson, J., Strindhall, J., Löfgren, S., et al. (2005). An immune risk phenotype, cognitive impairment, and survival in very late life: impact of allostatic load in Swedish octogenarian and nonagenarian humans. J. Gerontol. A. Biol. Sci. Med. Sci. 60, 556-565. doi: 10.1093/gerona/60.5.556

Wikby, A., Månsson, I. A., Johansson, B., Strindhall, J., and Nilsson, S. E. (2008). The immune risk profile is associated with age and gender: findings from three Swedish population studies of individuals 20-100 years of age. Biogerontology 9, 299-308. doi: 10.1007/s10522-0089138-6

Winkler, T. H., and Waisman, A. (2014). With a little help from my old T cell: memory follicular T helper cells driving autoimmunity? Eur. J. Immunol. 44, 2869-2871. doi: 10.1002/eji.201445101

Yamamoto, T., Iwamoto, N., Yamamoto, H., Tsukamoto, T., Kuwano, T., Takeda, A., et al. (2009). Polyfunctional $\mathrm{CD}^{+}{ }^{+} \mathrm{T}$-Cell induction in neutralizing antibody-triggered control of simian immunodeficiency virus infection. J. Virol. 83, 5514-5524. doi: 10.1128/JVI.00145-09

Yano, S., Ghosh, P., Kusaba, H., Buchholz, M., and Longo, D. L. (2003). Effect of promoter methylation on the regulation of IFN- $\gamma$ gene during in vitro differentiation of human peripheral blood $\mathrm{T}$ cells into a Th2 population. J. Immunol. 171, 2510-2516. doi: 10.4049/jimmunol.171. 5.2510

Zediak, V. P., Wherry, E. J., and Berger, S. L. (2011). The contribution of epigenetic memory to immunologic memory. Curr. Opin. Genet. Dev. 21, 154-159. doi: 10. 1016/j.gde.2011.01.016

Zhang, W., Brahmakshatriya, V., and Swain, S. L. (2014). CD4 T cell defects in the aged: causes, consequences and strategies to circumvent. Exp. Gerontol. 0 , 67-70. doi: 10.1016/j.exger.2014.01.002

Zhou, M., Zou, R., Gan, H., Liang, Z., Li, F., Lin, T., et al. (2014). The effect of aging on the frequency, phenotype and cytokine production of human blood CD4 + CXCR5 $+\mathrm{T}$ follicular helper cells: comparison of aged and young subjects. Immun. Ageing 11:12. doi: 10.1186/1742-493 3-11-12

Conflict of Interest Statement: The authors declare that the research was conducted in the absence of any commercial or financial relationships that could be construed as a potential conflict of interest.

Copyright $\odot 2016 \mathrm{Tu}$ and Rao. This is an open-access article distributed under the terms of the Creative Commons Attribution License (CC BY). The use, distribution or reproduction in other forums is permitted, provided the original author(s) or licensor are credited and that the original publication in this journal is cited, in accordance with accepted academic practice. No use, distribution or reproduction is permitted which does not comply with these terms. 